\title{
The Influence of Product Innovation and Product Quality on Consumer Purchase Interest in PT. Alfasindo Metal in Jakarta
}

\author{
Priehadi Dhasa Eka \\ Univesitas Pamulang \\ E-mail: dosen01577@unpam.ac.id
}

(Received: June-2019; revised: August -2019; published: December -2019)

\begin{abstract}
This study aims to determine the effect of product innovation and product quality on consumer buying interest at PT. Alfasindo Metal in Jakarta. The method used was explanatory research with a sample of 96 respondents. The analysis technique uses statistical analysis with regression testing, correlation, determination and hypothesis testing. The results of this study Product Innovation significantly influence consumer interest by $40.8 \%$, the hypothesis test obtained significance $0,000<0.05$. Product quality has a significant effect on consumer buying interest by $41.5 \%$, hypothesis testing obtained significance of 0,000 $<0.05$. Product innovation and product quality simultaneously have a significant effect on consumer buying interest of $51.2 \%$, the hypothesis test obtained a significance of $0,000<0.05$.
\end{abstract}

Keywords: Product Innovation; Product Quality; Consumer Purchase Interest.

\section{INTRODUCTION}

As a consequence of lifestyle changes, many companies are competing to produce quality products, this happens because consumers' needs for an item are increasingly varied and more selective. Seeing this the company also competes to produce products and develop products that are tailored to the tastes and needs of consumers. In general, companies make product innovations to win consumers from competitors (Meidutè-Kavaliauskienè et al., 2014; Tikollah \& Samsinar, 2019; Waris, 2015; Wirawan, 2015). In addition, innovation provides more value for innovator companies that can be pioneers to have the opportunity to get a positive image and reputation for their innovation power and prospectiveness in opening markets (M Aras et al., 2018; Muh Aras et al., 2017; Muhammad Aras et al., 2018; Giese \& Cote, 2000; Irmal et al., 2020; Zainal et al., 2018).

In competitive conditions, it is very dangerous for a company to only rely on existing products without certain efforts for its development. Therefore, every company in maintaining and increasing sales and their target markets need to make efforts to improve products produced in a better direction so that it can provide usability, satisfaction, and greater attractiveness (Dapkevičius \& Melnikas, 2011; Dharma \& Akib, 2005; Nur et al., 2019; Sunarsi, 2019, 2019).

With a deep understanding of consumers will enable marketers to influence consumer decisions, so consumers want to buy what is offered by marketers. One of the keys to success of a marketing strategy is to create product innovations that fit the needs and wants of the target market. Product innovation is closely related to the creation of new products. This is because product innovation is the application of new ideas or ideas into products so that new products 


\author{
198 |Jurnal Administrare: Jurnal Pemikiran Ilmiah dan Pendidikan Administrasi Perkantoran \\ Volume 6 No. 2 July - December 2019. Pages 197-206
}

are created. Thus a successful product is a product that can be accepted by consumers with prices, attributes, and appearance that meet the needs and desires of consumers.

Development of a product, producers must consider aspects of quality that will support the product's position on the market. Quality is one of the factors that consumers consider before buying a product, quality is a condition of an item based on an assessment of its conformity with established measurement standards. The more in accordance with the standards set, the product or service is judged to be of more quality (Handoko, 2002: in Bahchriansyah, 2011).

Consumer assessment of a product will affect consumer buying interest. Interest (intention) to buy a particular brand occurs when a desire arises to buy a product in the future (Muh Aras et al., 2017; Peter \& Olson, 2014; Puccinelli et al., 2009; Setiadi, 2003; Sunaryo, 2011). Thus someone who has an interest in buying a certain product indicates a desire to buy the product in the future. Along with the development of technology, Indonesian people, especially those living in urban areas began to experience lifestyle changes.

Based on the description above, the author is interested in conducting research to find out the extent to which product innovation and product quality affect consumer buying interest. For this reason, the authors conducted a study entitled "The Effect of Innovation and Product Quality on Consumer Purchase Interests"

\title{
METHOD
}

The type of research used is explanatory research (Creswell \& Creswell, 2017). The population in this study amounted to 96 respondents PT. Alfasindo Metal in Jakarta. The sampling technique in this study is saturated sampling, where all members of the population are sampled. Thus the sample in this study amounted to 96 respondents. In analyzing the data used the instrument test, classical assumption test, regression, coefficient of determination and hypothesis testing.

\section{RESULT AND DISCUSSION}

\section{Descriptive Analysis}

In this test used to determine the highest minimum and maximum scores, ratting scores and standard deviations of each variable. The results, can be seen in table 1 .

Table 1.

Results of Descriptive Statistics Analysis

\begin{tabular}{lr|r|r|r|r}
\hline \multicolumn{7}{c}{ Descriptive Statistics } \\
\hline & N & Minimum & Maximum & Mean & Std. Deviation \\
\hline Product Innovation (X1) & 96 & 32 & 48 & 38.43 & 3.865 \\
\hline Product Quality (X2) & 96 & 30 & 45 & 38.40 & 3.701 \\
\hline Consumer Purchase Interest (Y) & 96 & 32 & 46 & 39.09 & 3.590 \\
\hline Valid N & 96 & & & & \\
\hline
\end{tabular}


Product innovation obtained a minimum variance of 32 and a maximum variance of 48 with a ratting score of 38.42 with a standard deviation of 3.865. Product Quality obtained a minimum variance of 30 and a maximum variance of 45 with a ratting score of 38.40 with a standard deviation of 3.701. Consumer Purchase Interest obtained a minimum variance of 32 and a maximum variance of 46 with a ratting score of 39.09 with a standard deviation of 3.590 .

\section{Verification Analysis}

This analysis is intended to determine the effect of independent variables on the dependent variable. The test results can be seen in Tables 2 to 8 .

\section{Multiple Regression Analysis}

This regression test is intended to determine changes in the dependent variable if the independent variable changes. The test results are in table 2 .

Table 2.

Multiple Regression Testing Results

\begin{tabular}{|c|c|c|c|c|c|}
\hline \multirow[b]{3}{*}{ Model } & \multicolumn{3}{|c|}{ Coefficients $^{\mathbf{a}}$} & \multirow[b]{3}{*}{$\mathrm{t}$} & \multirow[b]{3}{*}{ Sig. } \\
\hline & \multicolumn{2}{|c|}{$\begin{array}{c}\text { Unstandardized } \\
\text { Coefficients }\end{array}$} & \multirow{2}{*}{$\begin{array}{c}\begin{array}{c}\text { Standardized } \\
\text { Coefficients }\end{array} \\
\text { Beta }\end{array}$} & & \\
\hline & B & Std. Error & & & \\
\hline 1 (Constant) & 10.011 & 2.959 & & 3.383 & .001 \\
\hline $\begin{array}{l}\text { Product Innovation } \\
\text { (X1) }\end{array}$ & .363 & .085 & .391 & 4.279 & .000 \\
\hline $\begin{array}{l}\text { Product Quality } \\
\text { (X2) }\end{array}$ & .394 & .089 & .406 & 4.439 & .000 \\
\hline
\end{tabular}

a. Dependent Variable: Consumer Purchase Interest (Y)

Based on the test results in the above table, the regression equation $\mathrm{Y}=10.011+$ $0.363 \mathrm{X} 1+0.394 \mathrm{X} 2$ is obtained. From the equation explained as follows:

1) A constant of 10,011 means that if there is no Product Innovation and Product Quality, there is a Consumer Purchase Interest value of 10,011 points.

2) Product Innovation regression coefficient of 0.363 , this number is positive, meaning that every time there is an increase in Product Innovation of 0.363, Consumer Purchase Interest will also increase by 0.363 points.

3) Product Quality regression coefficient of 0.394 , this number is positive, meaning that every time there is an increase in Product Quality of 0.394, Consumer Purchase Interest will also increase by 0.394 points.

\section{Correlation Coefficient Analysis}

Correlation coefficient analysis is intended to determine the degree of relationship strength of the independent variables on the dependent variable either partially or simultaneously. The test results in table 3 . 
200|Jurnal Administrare: Jurnal Pemikiran Ilmiah dan Pendidikan Administrasi Perkantoran Volume 6 No. 2 July - December 2019. Pages 197-206

Table 3

Test Results for Product Innovation Correlation Coefficient on Consumer Purchase Interest. Correlations $^{\mathbf{b}}$

\begin{tabular}{llr|r}
\hline & \multicolumn{1}{c}{$\begin{array}{c}\text { Product } \\
\text { Innovation (X1) }\end{array}$} & \multicolumn{2}{c}{$\begin{array}{c}\text { Consumer Purchase } \\
\text { Interest (Y) }\end{array}$} \\
\hline $\begin{array}{l}\text { Product Innovation } \\
\text { (X1) }\end{array}$ & $\begin{array}{l}\text { Pearson } \\
\text { Correlation }\end{array}$ & 1 & $.639^{* *}$ \\
\cline { 2 - 4 } & Sig. (2-tailed) & & .000 \\
\hline $\begin{array}{l}\text { Consumer Purchase } \\
\text { Interest (Y) }\end{array}$ & $\begin{array}{l}\text { Pearson } \\
\text { Correlation }\end{array}$ & $.639^{* *}$ & 1 \\
\cline { 2 - 4 } & Sig. (2-tailed) & & .000 \\
\hline
\end{tabular}

**. Correlation is significant at the 0.01 level (2-tailed).

b. Listwise $\mathrm{N}=96$

Based on the test results obtained a correlation value of 0.639 means that Product Innovation has a strong relationship to Consumer Purchase Interest.

Table 4

Correlation Coefficient Testing Results Product Quality Against Consumer Purchase Interest.

Correlations $^{\text {b }}$

\begin{tabular}{llr|r}
\hline & & $\begin{array}{c}\text { Product Quality } \\
\text { (X2) }\end{array}$ & \multicolumn{2}{c}{$\begin{array}{c}\text { Consumer Purchase } \\
\text { Interest (Y) }\end{array}$} \\
\hline Product Quality (X2) & Pearson Correlation & 1 & $.645^{* *}$ \\
\cline { 2 - 4 } & Sig. (2-tailed) & & .000 \\
\hline Consumer Purchase & Pearson Correlation & $.645^{* *}$ & 1 \\
\cline { 2 - 4 } Interest (Y) & Sig. (2-tailed) & .000 & \\
\hline
\end{tabular}

**. Correlation is significant at the 0.01 level (2-tailed).

b. Listwise $\mathrm{N}=96$

Based on the test results obtained a correlation value of 0.645 means that Product Quality has a strong relationship to Consumer Purchase Interest.

Table 5.

Simultaneous Correlation Test Results Product Innovation and Product Quality Simultaneously Against Consumer Purchase Interest.

Model Summary

\begin{tabular}{lr|r|r|r}
\hline Model & R & R Square & Adjusted R Square & Std. Error of the Estimate \\
\hline 1 & $.715^{\mathrm{a}}$ & .512 & .501 & 2.535 \\
\hline
\end{tabular}

a. Predictors: (Constant), Product Quality (X2), Product Innovation (X1) 
Based on the test results obtained a correlation value of 0.715 means that Product Innovation and Product Quality simultaneously have a strong relationship to Consumer Purchase Interest.

\section{Analysis of the Coefficient of Determination}

Analysis of the coefficient of determination is intended to determine the percentage of influence of the independent variable on the dependent variable either partially or simultaneously. The test results are as follows:

Table 6

Test Results for the Innovation Determination Coefficient of Consumer Purchase Interest.

Model Summary

\begin{tabular}{lr|r|r|r}
\hline Model & R & \multicolumn{1}{c|}{ R Square } & Adjusted R Square & Std. Error of the Estimate \\
\hline 1 & $.639^{\mathrm{a}}$ & .408 & .402 & 2.776 \\
\hline
\end{tabular}

a. Predictors: (Constant), product innovation (X1)

Based on the test results obtained a determination value of 0.408 means that Product Innovation has an influence contribution of $40.8 \%$ on Consumer Purchase Interest.

Table 7

Test Results for the Determination of Product Quality Coefficient on Consumer Purchase Interest.

Model Summary

\begin{tabular}{lr|r|r|r}
\hline Model & R & R Square & Adjusted R Square & Std. Error of the Estimate \\
\hline 1 & $.645^{\mathrm{a}}$ & .415 & .409 & 2.759 \\
\hline
\end{tabular}

a. Predictors: (Constant), Product Quality (X2),

Based on the test results obtained a determination value of 0.415 means that Product Quality has an influence contribution of $41.5 \%$ on Consumer Purchase Interest.

Table 8.

Test Results for the Innovation Determination Coefficient and Product Quality on Consumer Purchase Interests.

\section{Model Summary}

\begin{tabular}{lr|r|r|r}
\hline Model & R & \multicolumn{1}{c}{ R Square } & Adjusted R Square & Std. Error of the Estimate \\
\hline 1 & $.715^{\mathrm{a}}$ & .512 & .501 & 2.535 \\
\hline
\end{tabular}

a. Predictors: (Constant), Product Quality (X2), Product Innovation (X1)

Based on the test results obtained a determination value of 0.512 means that Product Innovation and Product Quality simultaneously have an influence contribution of $51.2 \%$ on Consumer Purchase Interest, while the remaining $48.8 \%$ is influenced by other factors. 


\section{Hypothesis testing}

Partial hypothesis test ( $t$ test)

Hypothesis testing with $\mathrm{t}$ test is used to find out which partial hypotheses are accepted. First Hypothesis: There is a significant influence between Product Innovation on Consumer Purchase Interest.

Table 9.

Results of the Product Innovation Hypothesis Test Against Consumer Purchase Interest.

\section{Coefficients $^{\text {a }}$}

\begin{tabular}{|c|c|c|c|c|c|}
\hline \multirow[b]{2}{*}{ Model } & \multicolumn{2}{|c|}{$\begin{array}{c}\text { Unstandardized } \\
\text { Coefficients }\end{array}$} & \multirow{2}{*}{$\begin{array}{c}\text { Standardized } \\
\text { Coefficients }\end{array}$} & \multirow[b]{2}{*}{$\mathrm{t}$} & \multirow[b]{2}{*}{ Sig. } \\
\hline & B & Std. Error & & & \\
\hline $1 \quad$ (Constant) & 16.296 & 2.846 & & 5.726 & .000 \\
\hline Product Innovation (X1) & .593 & .074 & 639 & 8.051 & .000 \\
\hline
\end{tabular}

a. Dependent Variable: Consumer Purchase Interest (Y)

Based on the test results in the above table, the value of $t$ count> $t$ table or (8.051> 1.661) is obtained, thus the first hypothesis proposed that there is a significant influence between Product Innovation on Consumer Purchase Interest is accepted.

Table 10.

Hypothesis Test Results for Product Quality Against Consumer Purchase Interest.

\section{Coefficients $^{\mathrm{a}}$}

\begin{tabular}{|c|c|c|c|c|c|}
\hline \multirow[b]{2}{*}{ Model } & \multicolumn{2}{|c|}{$\begin{array}{c}\text { Unstandardized } \\
\text { Coefficients }\end{array}$} & \multirow{2}{*}{$\begin{array}{c}\begin{array}{c}\text { Standardized } \\
\text { Coefficients }\end{array} \\
\text { Beta }\end{array}$} & \multirow[b]{2}{*}{$\mathrm{t}$} & \multirow[b]{2}{*}{ Sig. } \\
\hline & B & Std. Error & & & \\
\hline (Constant) & 15.086 & 2.950 & & 5.113 & .000 \\
\hline Product Quality (X2) & .625 & .076 & 645 & 8.174 & .000 \\
\hline
\end{tabular}

a. Dependent Variable: Consumer Purchase Interest (Y)

Based on the test results in the above table, the value of $t$ count $>t$ table or $(8,174>$ $1,661)$ is obtained. Thus, the second hypothesis proposed that there is a significant influence between Product Quality on Consumer Purchase Interest is accepted.

\section{Simultaneous Hypothesis Test (Test F)}

Hypothesis testing with the F test is used to find out which simultaneous hypotheses are accepted. The third hypothesis There is a significant influence between Product Innovation and Product Quality on Consumer Purchase Interest. 
Table 11.

Hypothesis Test Results for Product Innovation and Product Quality Against Consumer Purchase Interest.

\begin{tabular}{|c|c|c|c|c|c|c|}
\hline \multicolumn{7}{|c|}{ ANOVA $^{\mathrm{a}}$} \\
\hline & & Sum of Squares & $\mathrm{df}$ & Mean Square & $\mathrm{F}$ & Sig. \\
\hline \multirow[t]{3}{*}{1} & Regression & 626.329 & 2 & 313.165 & 48.717 & $.000^{\mathrm{b}}$ \\
\hline & Residual & 597.827 & 93 & 6.428 & & \\
\hline & Total & 1224.156 & 95 & & & \\
\hline
\end{tabular}

a. Dependent Variable: Consumer Purchase Interest (Y)

b. Predictors: (Constant), Product Quality (X2), Product Innovation (X1)

Based on the test results in the above table, the calculated $F$ value $>\mathrm{F}$ table or (48.717> 2,700 ), thus the third hypothesis proposed that there is a significant influence between Product Innovation and Product Quality on Consumer Purchase Interest is accepted.

\section{Discussion}

\section{Effect of Product Innovation on Consumer Purchase Interest}

Product Innovation has a significant effect on Consumer Purchase Interest with a correlation of 0.639 or has a strong relationship with a contribution of $40.8 \%$. Hypothesis testing obtained $t$ value $>t$ table or $(8.051>1.661)$. Thus the first hypothesis proposed that there is a significant effect between Product Innovation on Consumer Purchase Interest is accepted.

\section{Effect of Product Quality on Consumer Purchase Interest}

Product Quality has a significant effect on Consumer Purchase Interest with a correlation of 0.645 or has a strong relationship with an influence contribution of $41.5 \%$. Hypothesis testing obtained values of $t$ arithmetic $>t$ table or $(8,174>1,661)$. Thus the second hypothesis proposed that there is a significant effect between Product Quality on Consumer Purchase Interest is accepted.

\section{Effect of Product Innovation and Product Quality on Consumer Purchase Interest}

Product Innovation and Product Quality have a significant effect on Consumer Purchase Interest by obtaining a regression equation $\mathrm{Y}=10,011+0,363 \mathrm{X} 1+0,394 \mathrm{X} 2$, a correlation value of 0,715 or having a strong relationship with a contributing effect of $51.2 \%$ while the remaining $48.8 \%$ is influenced another factor. Hypothesis testing obtained $\mathrm{F}$ value $>\mathrm{F}$ table or (48.717> 2.700). Thus the third hypothesis proposed that there is a significant effect between Product Innovation and Product Quality on Consumer Purchase Interest is accepted. 
204 Jurnal Administrare: Jurnal Pemikiran Ilmiah dan Pendidikan Administrasi Perkantoran Volume 6 No. 2 July - December 2019. Pages 197-206

\section{CONCLUSION}

Product Innovation has a significant effect on Consumer Purchase Interest with a contribution of $40.8 \%$. Hypothesis testing obtained $t$ count $>t$ table or (8.051>1.661). Product Quality has a significant effect on Consumer Purchase Interest with an influence contribution of $41.5 \%$. Hypothesis testing obtained value of $t$ count $>t$ table or $(8,174>1,661)$. Product Innovation and Product Quality have a significant effect on Consumer Purchase Interest with a contribution of $51.2 \%$ while the remaining $48.8 \%$ is influenced by other factors. Hypothesis testing obtained the value of $\mathrm{F}$ count $>\mathrm{F}$ table or $(48.717>2,700)$.

\section{REFERENCES}

Aras, M., Jasruddin, J., Akib, H., \& Syam, H. (2018). Marketing Mix Study at Hero Tailor. IOSR Journal of Business and Management (IOSR-JBM), 20(4), 45-51.

Aras, M., Syam, H., Haris, H., Jasruddin, M., \& Akib, H. (2018). The Analysis of Mix Marketing System Toward The Perfomance of Convection Business in Makassar. 1st International Conference on Social Sciences (ICSS 2018).

Aras, M., Syam, H., Jasruddin, J., Akib, H., \& Haris, H. (2017). The effect of service marketing mix on consumer decision making. International Conference on Education, Science, Art and Technology, 108-112.

Creswell, J. W., \& Creswell, J. D. (2017). Research design: Qualitative, quantitative, and mixed methods approaches. Sage publications.

Dapkevičius, A., \& Melnikas, B. (2011). Influence of Price and Quality to Customer Satisfaction: Neuromarketing Approach. Mokslas - Lietuvos Ateitis. https://doi.org/10.3846/144

Dharma, S., \& Akib, H. (2005). The Influence of Job Satisfaction on Work Performance: a Theoretical Approach. Manajemen USAHAWAN Indonesia,(2), 30-33.

Giese, J., \& Cote, J. (2000). Defining consumer satisfaction. Academy of Marketing Science Review.

Irmal, I., Gustiarani, E., \& Sunarsi, D. (2020). Pengaruh E-Marketing dan E-CRM terhadap ELoyalty Pengunjung Situs Website www. Cangkirbogor.com. Jurnal Ekonomi Efektif, 2(2).

Meidute-Kavaliauskienè, I., Aranskis, A., \& Litvinenko, M. (2014). Consumer Satisfaction with the Quality of Logistics Services. Procedia - Social and Behavioral Sciences. https://doi.org/10.1016/j.sbspro.2013.12.877

Nur, F., Rahman, U., \& Musdalifa, M. (2019). Effect of Motivation and Job Satisfaction on Teacher Performance in Private Madrasah Aliyah in Maros Regency. Jurnal Ilmiah Ilmu Administrasi Publik, 9(1), 9-18.

Peter, J. P., \& Olson, J. C. (2014). Perilaku Konsumen dan Strategi Pemasaran. In salemba 
empat.

Eka, P. D. (2017). Analisis Pengaruh Kecerdasan Intelektual, Kecerdasan Emosi dan Kepemimpinan terhadap Kinerja Karyawan (Studi Pada PT Bank BTN Cabang Ciputat). PEKOBIS: Jurnal Pendidikan, EKonomi, dan Bisnis, 2(3), 65-76.

Puccinelli, N. M., Goodstein, R. C., Grewal, D., Price, R., Raghubir, P., \& Stewart, D. (2009). Customer Experience Management in Retailing: Understanding the Buying Process. Journal of Retailing. https://doi.org/10.1016/j.jretai.2008.11.003

Rialmi, Z., \& Morsen, M. (2020). Pengaruh Komunikasi Terhadap Kinerja Karyawan PT Utama Metal Abadi. JENIUS, 3(2), 221-227.

Rialmi, Z. (2017). Pengaruh Keadilan Prosedural Yang Diterapkan Kepemimpinan Pegawai Dan Kepuasan Kerja Pegawai Terhadap Kinerja Dari Pegawai BPBD Provinsi Riau. Jurnal Mandiri: Ilmu Pengetahuan, Seni, dan Teknologi, 1(2), 353-374.Rivai Veithzal (2015) Manajemen Sumber Daya Manusia Untuk Perusahaan. Jakarta: PT Raja Grafindo Persada.

Setiadi, N. J. (2003). Perilaku Konsumen. Aplikasi Manajemen.

Sunarsi. D, Aris Baharuddin. 2019. The Effect of Service Quality and Price Accuracy on Consumer Confidence and Implications for Sales Increase. PINISI Discretion Review. Vol. 3. No. 2. Maret 2019.

Sunaryo, S. (2011). Analisis Pengaruh ROA (Return On Assets), ROE (Return On Equity), dan EPS (Earning Per Share) terhadap Harga Saham pada Kelompok Industri Barang Konsumsi yang Terdaftar di BEI (Bursa Efek Indonesia). Binus Business Review. https://doi.org/10.21512/bbr.v2i1.1121

Tikollah, M. R., \& Samsinar, S. (2019). The Effect of Company Size, Operating Profit/Loss, and Reputation of KAP Auditor on Audit Delay. Jurnal Ilmiah Ilmu Administrasi Publik, 9(1), 87-94.

Waris, A. P. M. dan A. (2015). Effect of Training, Competence and Discipline on Employee Performance in Company (Case Study in PT. Asuransi Bangun Askrida). Procedia Social and Behavioral Sciences. https://doi.org/10.1016/j.sbspro.2015.11.165

Wirawan. (2015). Manajemen Sumber Daya Manusia Indonesia. In Depok.

Zainal, H., Parinsi, K., Hasan, M., Said, F., \& Akib, H. (2018). The influence of strategic assets and market orientation to the performance of family business in Makassar City, Indonesia. Academy of Strategic Management Journal, 17(6). 
206| Jurnal Administrare: Jurnal Pemikiran Ilmiah dan Pendidikan Administrasi Perkantoran Volume 6 No. 2 July - December 2019. Pages 197-206 